\title{
Neurologists and COVID-19
}

\section{A note on courage in a time of uncertainty}

Renée A. Shellhaas, MD, MS

Neurology ${ }^{\circledR}$ 2020;94:855-857. doi:10.1212/WNL.0000000000009496

Neurologists are used to uncertainty — diagnoses are frequently challenging, too often there are limited treatment options, and unpredictable prognoses are our bread and butter. When colleagues struggle to communicate bad news, they regularly turn to us. We practice staying steady and calm amidst our patients' fears, confusion, suffering, and anxiety. We listen, perform detailed examinations, and do our best to provide helpful insights. This emphasis on listening and thoughtful problem solving is the core of our art and should be front and center as we partner with colleagues to face an unprecedented set of challenges related to the Coronavirus Disease 2019 (COVID-19) pandemic.

Today, the path is not clear and the solutions cannot be formulaic. As neurologists and community members, we must find ways to navigate forward, step up, adapt, and forge ahead not only in figuring out how to take care of our patients but to also take care of ourselves and to maintain the integrity of our clinical practice and research programs. Through dialogues with colleagues within and outside of our field, I have become convinced that many of the skills we cultivate as neurologists can support us in this time of intense need and complex problems.

\section{How do we decide what actions are of highest value?}

In the last few weeks, I have witnessed inspiring leaders step up to face our current challenges and privately heard them share despair and deep-seated anxiety that their efforts will be inadequate. Many have named the problem of time and resource allocation when everything seems urgent and everything is important. Not only do they (and I) worry about their current patients but also the danger of exposure to COVID-19 for themselves, their colleagues and staff, and their families. At the same time, as hospital systems are reorganizing around us, we must juggle the needs of children who are suddenly out of school, elderly parents we are afraid to visit but need to support, and a host of other day-to-day practical problems that cannot simply be put aside. There are more demands now everyday than we can possibly hope to take care of. This is the time to separate the critical from the urgent or merely important. Instead of thinking we can or should take care of everything, we have to realize that our circumstance requires us to be ruthlessly strategic in dedicating our time to critical issues and delay or let go of the other things.

\section{By the time we can articulate a plan, it is already outdated}

This is a time of rapidly evolving, thorny problems that require incredibly complex solutions. Before COVID-19, there were structures, protocols, and patterns for our professional and personal lives. Today, each day is unpredictable. New and different decisions are required without any precedent or guarantee that they will work or will be relevant tomorrow. Many of us feel disorganized, unsettled, and disoriented - this is the truth of the current situation. This is not an excuse for inaction. This is a call for us to name our fears, keep taking deep breaths, and plan our next moves understanding full well that today's plan for tomorrow might have to change before the sun rises.

\section{Correspondence}

Dr. Shellhaas

shellhaa@med.umich.edu

\section{MORE ONLINE}

\section{COVID-19 Resources}

For the latest articles, invited commentaries, and blogs from physicians around the world NPub.org/COVID19 


\section{Expect emotional flooding and find ways to remain steady}

Emotional flooding happens when our nervous system is saturated with stimuli-think back to your neuroanatomy courses and the function of the prefrontal cortex, anterior cingulate, and limbic system. When we exceed our ability to process the onslaught of incoming information, we shift to "fight or flight" mode. The "flight" might mean not being able to focus or concentrate, being confused about a decision, getting angry or upset-losing our equilibrium. Look for this in yourself and the people around you. When we recognize emotional flooding, we need to give ourselves permission to hit pause, just for a moment. Take a few deep breaths or make a list of things that are overwhelming you. Break tasks into smaller pieces, ask advice, go for a walk, or find a quiet place for a minute to give yourself a chance to reset. Then, pick the single next item you will deal with and take that single next step.

\section{Pivot quickly and be open to learning new ways of practice}

As neurologists, we depend on face-to-face engagement with patients and families. Our clinical practices have, by necessity, changed dramatically as the reality of the pandemic sets in. I am awed by the immediate pivot to widespread telemedicine implementation across so many medical centers. There are clearly gigantic logistical hurdles to pull together a widespread, financially sustainable, and patient-centered program for telemedicine. COVID-19 might just be the stimulus we needed to launch ourselves in this important direction. I suspect that there will be no going back to the old model of long-distance patient travels for routine clinical encounters. This is a good thing. For now, my young patients have found it interesting to see what their doctor's makeshift basement office looks like!

\section{Taking the long view is hard, but we cannot ignore it}

Epilepsy does not stop just because there is a pandemic disease. Neither do stroke, multiple sclerosis, dementia, muscular dystrophy, or any of their comorbidities. We need to face the challenges of how to manage our current patients. We have to make complex decisions about the risks and benefits of immunosuppression for autoimmune neurologic diseases or infantile spasms or hospital visits for gene therapy infusions. We cannot know how long the COVID-19 pandemic will persist, so we balance the risk of a permanently poor outcome without treatment against the chance of iatrogenic or community COVID-19 exposure and serious adverse consequences. This is a time for creative, team-based thinking for individual patients and system-wide approaches. At the same time, we must all plan for the imminent flood of new patients whose needs could not be met while our resources are necessarily diverted to lifesaving measures for COVID-19 victims. For our specialty, this strategic planning may be the most defining aspect of our response to COVID-19.

Similarly, researchers-whether launching a career, leading established teams, or mentoring junior faculty and trainees-must cope with a whole new level of prioritization. It is unrealistic to think this will be a time when multiple new grants and articles are written-the needs for our clinical and leadership skills, and care for our families must take precedent. The abrupt end to clinical subject recruitment and shuttering of laboratories will have long-lasting impact on our academic lives. We will need to devise new and creative means for dissemination of the data we have yet to present because academic conferences are on hold for an undetermined amount of time. I have heard colleagues despair that this could be the end of their research careers. Yet, there is hope. Universities and funding agencies have been quick to publish guidance and push out messages of support. This is going to be difficult, but there will be a way forward. Those who succeed will be a generation of unprecedented resilience and creativity.

\section{This is a time when mindset matters}

This is a time to focus on what can be done, one hour at a time, one action at a time. As neurologists, we know better than most the impact stress and anxiety can have on the brain's ability to function. We can direct and manage our selftalk as we concentrate on the critical issues. Although it may be difficult, we can stay balanced and focus on what we can do-individually and collectively. There is no question that when people pull together, share burdens, and have a common purpose, there is a sense of belonging and making a difference. I hope that a deep sense of community will be a lasting effect of COVID-19.

This is a time for courage, empathy, self-care, and teamwork. It is also a time of confusion and overwhelming emotion. I encourage you to use your core neurology skills-listening and thoughtful problem solving-and to walk with humble confidence as you take your immediate next step and the one after that. Let us band together now, for the sake of our patients and of our own humanity.

\section{Acknowledgment}

I am grateful to Madelyn Yucht (CEO, Summit Executive Advisory Group, a leadership expert and master executive coach) for her generous assistance in crafting and reviewing this commentary.

\section{Study funding}

No targeted funding reported. 


\section{Disclosure}

R. Shellhaas serves as Associate Editor for Neurology. Her research is supported by NIH, PCORI, the Pediatric Epilepsy Research Foundation, and the University of Michigan
Woodson Pediatric Research Fund. She receives royalties from UpToDate for authorship on topics related to neonatal seizures and is a consultant for the Epilepsy Study Consortium. Go to Neurology.org/N for full disclosures. 


\section{Neurology}

\section{Neurologists and COVID-19: A note on courage in a time of uncertainty \\ Renée A. Shellhaas \\ Neurology 2020;94;855-857 Published Online before print April 1, 2020 \\ DOI 10.1212/WNL.0000000000009496}

This information is current as of April 1, 2020

Updated Information \&
Services

Citations

Permissions \& Licensing

Reprints including high resolution figures, can be found at:

http://n.neurology.org/content/94/20/855.full

This article has been cited by 2 HighWire-hosted articles: http://n.neurology.org/content/94/20/855.full\#\#otherarticles

Information about reproducing this article in parts (figures,tables) or in its entirety can be found online at:

http://www.neurology.org/about/about_the_journal\#permissions

Information about ordering reprints can be found online:

http://n.neurology.org/subscribers/advertise

Neurology ${ }^{\circledR}$ is the official journal of the American Academy of Neurology. Published continuously since 1951, it is now a weekly with 48 issues per year. Copyright (C 2020 American Academy of Neurology. All rights reserved. Print ISSN: 0028-3878. Online ISSN: 1526-632X.

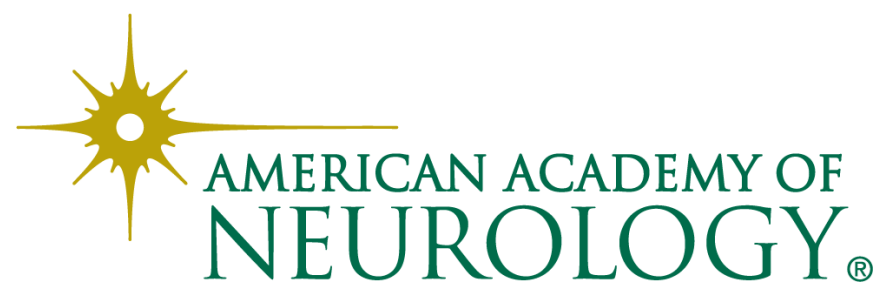

